\title{
THE REVIVAL OF PROTECTIONISM IN THE MODERN WORLD: CASE STUDY OF UZBEKISTAN
}

\author{
Regina GAYNULINA \\ Riga Technical University, Riga, Latvia \\ Corresponding author e-mail: regina_gaynulina@mail.ru
}

\begin{abstract}
Since the publication of The Wealth of Nations by Adam Smith, in which marketbased economy free from government interventions was systematically defended, economics and philosophy have mostly parted ways, culminating in a clear distinction between how most economists and philosophers view the global economic order. Although it is now clear that trade liberalization, unlike protectionism, paves the way for economic development, many still argue that the countries are better off implementing protectionist measures. Even the developed countries today seem to slowly return protectionist policies, while the developing ones commonly employ them fully. In this research work, the author will analyze the recent trends in trade policymaking as well as conduct a case study of Uzbekistan to see what impact the decades of protectionism and recent trade-liberalization reforms made on the country's economic growth. The aim of the work is to identify and reveal the features of new protectionism in the context of globalization of the world economy and the related contradictions and to provide recommendations for Uzbek authorities based on the empirical findings. There is a very limited number of researches made in the field of trade policy in Uzbekistan, therefore this work will contribute to both Uzbekistan and global scientific societies, as the case study can be used to improve the current situation in the country, as well as it can be applied to the countries of a similar economic background (precisely present at the same geographic region) for the same purposes. The hypothesis proposed for this research is: When the country implements high protectionist measures it faces lack of money inflow, which consequently leads to a slow-down in economic growth.
\end{abstract}

Keywords: Competition, Free-trade, Foreign direct investment, Uzbekistan, Trade barriers, Protectionism.

JEL Classification: F13

\section{INTRODUCTION}

Most economists argue that liberalized trade is the best possible solution to fight poverty, whereas philosophers usually promote protectionism or other non-liberal economic models as the fairest development policy for poverty reduction.

Although most of the developed countries tend to lean towards free trade economy, in recent years protectionism policies are becoming increasingly popular among more and more countries. At the beginning of 2009, the World Bank reported that 17 out of the G20 members failed to keep promises of not increasing protectionism. Moreover, they have been determined on defending the domestic industry, by filing complaints with the WTO over dumping, flooding another country with goods well below the market price. The WTO, in turn, portrayed bailouts as potentially harmful for trade, due to denial of market share for 
more efficient producers, including foreign suppliers, supporting operations of uncompetitive or insolvent firms (Evenett, 2009).

Notwithstanding previous evidence of the increased protectionism in economic downturns, reduced world trade and consequently government losses, governments of many countries still believe that this is the most effective economic policy. The implementation of protectionism policies contradicts free trade and global market volatility, reverses the process of integration and specialization, emphasizing in-country problems and tasks as top priorities. A modern protectionist mechanism is a set of complementary means that are constantly changing under the influence of primarily the objective processes of development of the productive forces and interests of the main groups of domestic companies. Among the protectionist tools, there are traditional and relatively new, explicit and veiled, more or less effective from the point of view of the international community and, most importantly, both acceptable and unacceptable. In the conditions of the trend towards liberalization of international trade in the post-war period, all countries nevertheless apply import restrictions and subsidies to enterprises of a protectionist nature. Despite the increased regulation of the use of protectionist measures on a multilateral basis, they remain and, most probably, will continue to be among the main means of foreign trade policy, although acquiring new forms.

Considering the current economic situations in the counties worldwide: some are still fighting with the effects of crisis, others are approaching economic recessions due to the sanction-wars, others are trying to figure out what the change of presidency will lead the country to - the debate on which policy is more applicable to ensure stability and continuous economic growth is becoming increasingly topical. Many experts argue that free-trade shall become even less governmentally controlled, while the governments, on the contrary, are introducing more and more protectionist measures. This paper is aimed to analyze the legitimacy of protectionism in the 21 st century based on theoretical and empirical research.

The research object is protectionism in the modern world, whereas the research subject is the causes and consequences of protectionism policies implementation and the effects of the recent trade liberalization reform in Uzbekistan.

The aim of the paper is to identify and reveal the features of new protectionism in the context of globalization of the world economy and the related contradictions applying it to the case study of Uzbekistan.

To achieve this goal, following objectives have been set:

1. Identification of the main reasons and comprehensive assessment of the consequences of the application of protectionist measures for the development of the national economy;

2. Identification of the socio-economic prerequisites and conditions for the implementation of protectionist policies in Uzbekistan;

3. Analysis of the scope, main directions, and forms of application of protective measures in Uzbekistan and effect of a recent liberalization reform.

Investigated correlations show the interrelation of trade freedom and foreign direct investment flows. The statistical analysis demonstrated that protectionism has a negative impact on FDI as well as on the unemployment rate, which is one of the main indicators of a country's prosperity. The findings from the interviews support the hypotheses that not only do barriers to trade not boost the improvement of performance in the protected sector but also promote corruption and push aside the foreign direct investment, which in turn slows 
down the economic growth in general and holds back the technological advancement needed to pursuit market competitiveness in particular.

\section{METHODOLOGY}

The effect of newly introduced liberalization policy was analyzed through in-depth interview with the country's scholars, businessmen and economists. Additionally, a regression analysis was performed to compare Uzbekistan's economy expansion (based on GDP figures, unemployment rate, FDI inflow and other factors) to the amount of protective or liberalizing measures implemented in the country.

\section{PROTECTIONISM}

Protectionism is one of the most complex and controversial phenomena in international trade, both theoretically and practically. Some economists justify protectionist policies and provide sufficiently strong arguments in support of them, while others condemn these policies and also convincingly substantiate their point of view. One of the reasons for the protectionist measures of governments can be the lack of competitiveness of domestic producers in a given country compared to producers in other countries due to the unevenness of economic development (McGowan, 2017). In addition to that, the episodic difficulties of the countries with the balance of payments require the operational restriction of imports, as well as an excessive increase in the share of imports in the consumption of important goods from the point of view of national security considerations (Mallick, 2014). These reasons seem justifiable for the protectionist policy since it aims to maintain the normal functioning of the market mechanism within the country in conditions when national economies coexist and closely interact with different efficiency. When this mechanism fails or when the domestic market becomes the object of aggression from the side of unscrupulous entrepreneurs who use budget funds protectionism is descent for failure (Krugman et al, 2018).

Many opponents of globalization in general and trade liberalization, in particular, argue that the notion of economic liberalization helping to alleviate poverty and to boost the economy has been tried and failed and should thereafter be disregarded. And certainly trade liberalization has been promoted as the path to development of economy for decades, however, to argue that such a developmental policy has been tried and found working is to ignore the fact that nearly every country in the world still creates barriers to trade, even if those barriers are more porous than those in the past.

Indeed, when arguing that in harsh reality developed countries' policies are inflicting enormous suffering on the world's poor, anti-globalization movement representatives and cosmopolitan philosophers, such as, for instance, Thomas Pogge (2016), must recognize such facts. Paradoxically, these authors and organizations' members refuse to recognize that developing world's protectionism, as bad as it is, is in fact dwarfed by the protectionism in the developed world, while admitting that trade barriers do exist, at least in the developed countries, and such barriers have a negative impact on economy boost and poverty reduction.

Nowadays, many members of WTO are questioning the role and future of the institution. The concerns are typically revolving around high foreign policy (as the case with the US) and the unequal benefits of international trade and non-discrimination. The newly grounded BRICS institution, which is comprised of Brazil, Russia, India, China, and South Africa, 
together with some other developed economies are additionally questioning the current spread of gains from trade. Trade-induced competitive specialization involves the adjustment period during which the workers need to relocate themselves to the more competitive firms and sectors of the economy (Dawar, 2018). These immediate losers from free trade tend not to see benefits, particularly while the economic growth is relatively low. In addition to that, the immediate losers from forced redundancies caused by the introduction of new technologies and new trade relations are usually socio-economically and geographically concentrated. To such communities, protectionism, being seen as an easy solution, is appealing. Domestic governments' ability to fix the local labor market significantly affects the extent to which support for further trade liberalization in highincome nations can be garnered (Evenett, 2017). According to the WTO reports, since the 2008 standstill pledge over 1400 trade-restrictive measures have been introduced by the members of G20. Many of them had only been removed 7 years after. More than 75 percent of the measures implemented in 2008 is still present. Approximately 60 percent of restrictive measures are trade defense measures ("WTO | Reports on recent trade developments news archive", 2015). The Global Trade Alert (GTA) database shows that there is a steady increase in protectionist policies implementation since the global financial crisis. By the end of 2015, almost 4000 protectionist measures worldwide were categorized as protectionist by the GTA. Similarly, to the GTA and WTO, the monitoring of potentially trade-restrictive policies showing a negative trend is revealed by the European Commission. According to the institution's report, the pace of removal has considerably worsened in the last years, whereas the number of new protectionist measures continues to rise sharply.

European countries, being amongst the pioneers of free trade currently also consider the lack of governmental intervention a threat and tend to increase the number of protectionist measures. The general public believes that the states would be better off with the greater protection of at least some sectors, and this is very well supported by the governments. Although the European Commission is tracking down the violations of free trade policies, nothing much has been done to reduce them.

\section{CASE STUDY OF UZBEKISTAN}

After gaining their independence, the countries of Central Asian (CA) region embarked on the path of a radical socio-economic and political transformation. Many of those countries, however, stuck to the implemented during the Soviet time's policy of protectionism, Uzbekistan not being an exception. For over 20 years of its independence, the country did not succeed in promoting its industries via protectionist support and today new economic reforms are on the way.

Despite all the shortcomings occurring during the rule of the first president Karimov, his key legacies were the preservation of sovereignty and maintenance of stability, which presented an opportunity for the new leader to launch new reforms from a position of strength and security, rather than in response to the crisis. This, more than anything else, augured well for their success. Under the presidency of Shavkat Mirziyoyev (2016-present), the newly elected president, new liberalization reforms have been introduced.

By the end of the 2017, more than 336,000 new jobs were created; exports and imports increased by 15.4 and 7.2 percent respectively, trade turnover with foreign countries inclined by more than 11 percent and this is not to mention a noticeable increase in the foreign direct investment inflow into the country (State Committee of Uzbekistan on statistics, 2018). The establishment of the office of Ombudsman aimed to protect the interest of foreign as well as 
domestic businesses, together with the creation of partnerships with the multilateral development banks are arguably the most successful measures taken to foreshadow significant improvements in the economic development of the country.

The World Bank approved investment projects in Uzbekistan in 2017 valued at more than 1 billion US dollars. Akihiko Nakao, the president of ADB, signed a 573 million US dollar worth loan agreement for the small business development, agriculture, road construction, and water supply projects. The European Bank for Reconstruction and Development provided the country with 100 million US dollars for small business projects, while Russia's Gazprombank invested 153 million US dollars. Leading German banks, including Deutsche Bank and Commerzbank, offered the country's National Bank for Foreign Economic Activities loans worth 950 million Euros (World Bank, 2018)ю

Using the indicators of protectionism in the country (the number of protective measures and the number of documents necessary to import a product), the unemployment rate, and the amount of foreign direct investment (FDI), the regression analysis has been performed. The statistical analysis produced by the author demonstrated that protectionism has a negative impact on FDI as well as on the unemployment rate, which is one of the main indicators of a country's prosperity. Thus, we can conclude, that the country benefits more from the liberalized trade than from the trade barriers. This statement was additionally proved by the interviews with the experts.

Last, but not least, using the past data the author managed to perform the regression analysis to predict economic development for the country through forecasting GDP, unemployment rate and inflation (Figure 1).

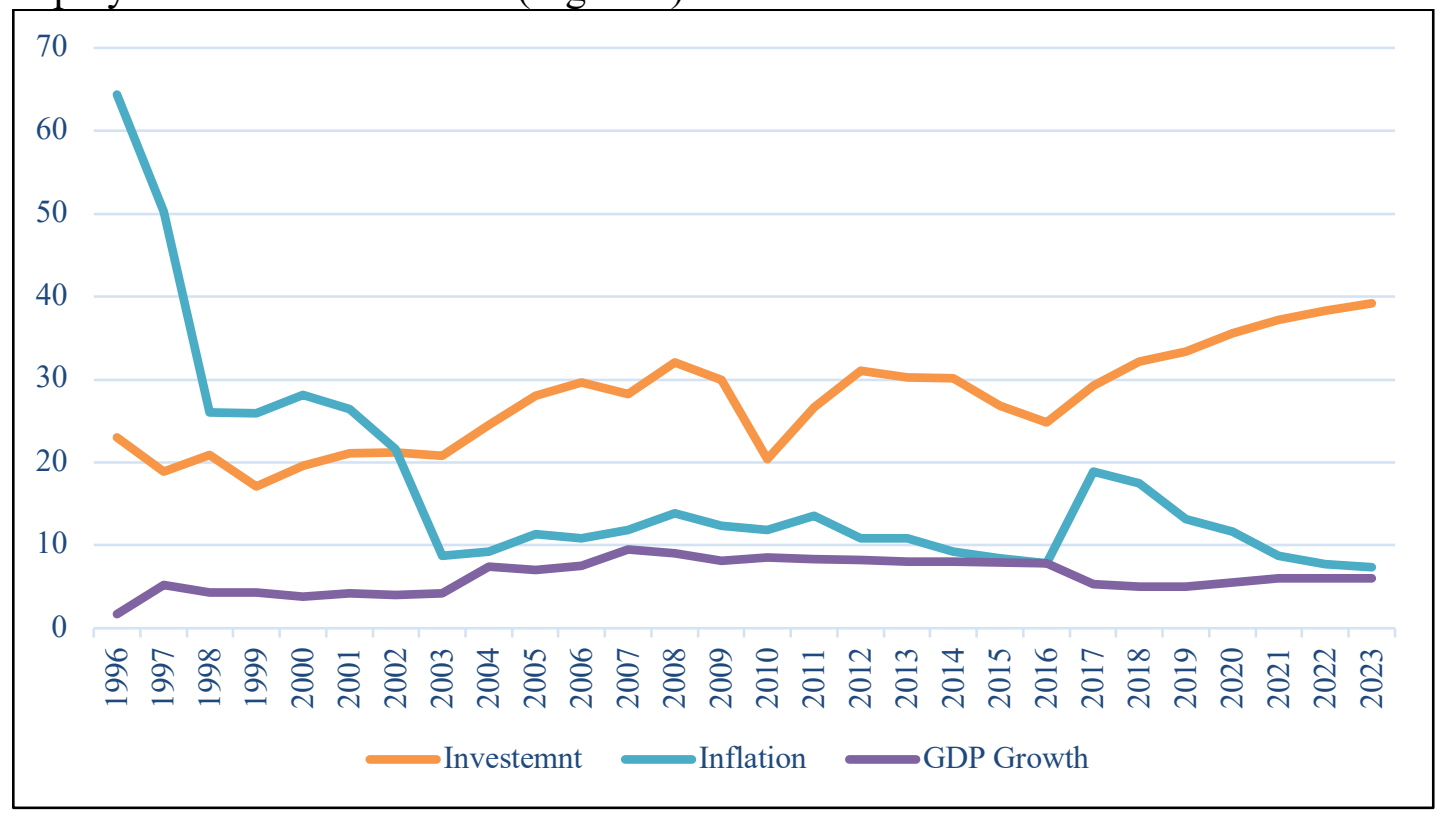

Fig. 1. Forecast of Uzbekistan macro-indicators (Created by the author).

To make a forecast for 5 years (2019-2023) the author used data from 1996 and ongoing 22 years. The data on investment was taken from The World Bank Database; inflation rates from International Monetary Fund and The World Bank; and the rate of GDP growth was also found in the database of The World Bank. To produce a forecast linear regression causal approach to forecasting was used. This means that not only historical performance, but also various factors (such as the number of liberalizing measures, rate of FDI, etc.) have been used, making the forecast more accurate. This data can be backed up by the data from recent 
World Bank report "Uzbekistan: Toward a New Economy". In this report specialists from the world bank analyze current situation in the country, with regard to recent trade liberalization reform and based on their own findings provide a forecast for the key economic growth indicators. The numbers produced by the World Bank correspond to the finding of this paper.

\section{CONCLUSION}

The findings from the literature review demonstrate, that together with the lack of beneficial impact on the economy, protectionism is believed to cause smuggling activities, which commonly lead to conflict situations within and outside the country that has protectionist policies implemented. Additionally, since the protectionist barriers limit the improvement in the industries they are not boosting, which means, along with other factors, no new vacancies are being created. This encourages unemployed people to involve illegal activities to make a living.

Despite all the disadvantages of protectionism, despite the overall aim to make the global trade free from governmental interventions, the reality dictates that there is still much to be done to achieve it. Many countries today, including the developed ones, either introduce new or preserve old protectionist measures (those implemented during the global financial crisis).

Many years of protectionism policy Uzbekistan's authorities were waiting for the industries to develop and boost the economy, however, the reality was quite the opposite. The protectionist measures lead the country to the expansion of the gap between the poor and the reach, promoted corruption and held back the improvement of general living conditions. Since 2016, however, after the changes in legislation aimed at opening trade, the country has undergone a significant positive shift. Citizens of the country are now exposed to a greater variety of products available at the market, the currency can freely be converted in banks, not at the black market as it was used to, the country has gained extraordinary amounts of foreign direct investment, which caused an increase in the number of jobs, more and more foreigners seek to open businesses in the country, especially in the free economic zones. All these happenings once again prove the positive influence of liberalized trade on the country's economy. Both, statistical analysis and interviews, show that high protectionist measures lead to a restricted amount of foreign direct investment, which, in turn, slow down the economic growth, whereas liberalized trade helps the economy to flourish.

\section{REFERENCES}

Dawar, K. (2018). Protectionism and international diplomacy. Retrieved from http://www.europarl.europa.eu/RegData/etudes/STUD/2018/603874/EXPO_STU(2018)603874_EN.pdf

Evenett, S. (2017). Cloth for Wine? The Relevance of Ricardo's Comparative Advantage in the 21st Century (1st ed., p. 3). London: CEPR Press.

Krugman, P., Obstfeld, M., \& Melitz, M. (2018). International economics (11th ed., pp. 57-64). Harlow [etc.]: Pearson Education.

Mallick, N. (2014). A Large Country Imposing Import Tariff: Optimal Import Tariff in Terms of Adjustment Weights. SSRN Electronic Journal. https://doi.org/10.2139/ssrn.2501155

McGowan, D. (2017). Digging Deep to Compete: Vertical Integration, Product Market Competition and Prices. The Journal Of Industrial Economics, 65(4), 683-718. https://doi.org/10.1111/joie.12157

Pogge, T. (2016). The Hunger Games. Food Ethics, 1(1), 9-27. https://doi.org/10.1007/s41055-016-0006-9

Regional Economic Outlook: Middle East and Central Asia | MCD REO | World economic and financial $\begin{array}{llllll}\text { surveys. } & \text { (2018). } & \text { Retrieved } & 14 & \text { April } & \text { 2018, }\end{array}$ https://www.imf.org/en/Publications/REO/MECA/Issues/2018/10/02/mreo1018 
Trushin, Eskender. 2019. Uzbekistan - Toward a New Economy : Country Economic Update (English). Washington, D.C. : World Bank Group. http://documents.worldbank.org/curated/en/866501562572675697/Uzbekistan-Toward-a-New-EconomyCountry-Economic-Update

WTO (2015). Reports on recent trade developments news archive. WTO. Retrieved from https://www.wto.org/english/news_e/archive_e/trdev_arc_e.htm 